\title{
Underemployment, Petty Production and Government Promotion Schemes in Senegal
}

\section{Chris Gerry}

Petty producers in Dakar are by no means a homogeneous element in the urban complex of production processes-a factor which has led to methodological errors being made in the approach to their study. The different strata of petty producers relate in different ways to the dominant forms of production and distribution, making the problem of analysis doubly difficult, but such difficulties recede considerably if the main thrust of the analysis deals with relationships rather than characteristics.

The blanket term 'petty producer' comprises artisans producing for individual clients as well as others who deal almost exclusively with the market. Irrespective of these differences, many petty producers must deal either directly or indirectily with the products and/or services of capitalist industry and commerce. Most petty producers depend upon such enterprises for access to their raw materials, acquisition of machinery and tools, and in many other minor ways. This proposition may sound facile, yet its significance is great, not merely in terms of dependence but also in terms of market-shares (where mutually interesting markets exist), and technical change.

In order to subsist or accumulate it is necessary to have some relationship with forms of production and appropriation extremely different from those in which one operates oneself; thus the dominant system has considerable ability to shape and restrict the activities of dependent sub-systems. That such sub-systems often appear to differ considerably from one another merely refiects the nature of the structural relationships in which they are involved. Hence markets in which petty production and distribution predominate are likely to be those in which it would be unprofitable for large-scale industry and/or commerce to engage. The symbiosis between petty and industrial production does not exclude the possibility of the penetration of industrial markets by the former's products; nevertheless, it militates severely against it at all levels, including the administrative. ${ }^{\prime}$ Additionally, since large sections of petty production depend upon articles and materials which are discarded by industrial or ancillary processes, changes in the latter's technology, form, or even its overall viability, have considerable effects upon dependent branches of petty production, to which industry feels no responsibility, if indeed it is aware of the relationship.

Petty production in its various forms depends upon capitalist industry and commerce to produce and, often, distribute the materials and equipment it requires; this 'dependence' originates in the quasi-monopolisation of these productive and distributive sub-processes by large and medium-size industry and commerce. In Senegal a multinational corporation currently produces large quantities of leather shoes, for which it depends upon local raw materials; it also benefits from state protection, whereas the petty producers do not. Certainly 'modernisation' has involved considerable changes for the craftsman cobbler, though his current use of plastic rather than traditional leather has usually been heralded as proof either of initiative or of his modernisation mentality, rather than the defensive action of dispersed, unorganised, relatively poor yet tenacious craftsmen responding to extensive encroachment upon their traditional markets.

There are two inextricably connected trends within the evolution of petty production and its external relationships; these relate to the continuing process of differentiation among petty producers. Some manage to obtain certain relations through small contracts or sub-contracts with medium or large commercial or industrial units. Similar changes in the operations of petty producers may evolve through their organisation by the State, involving the direct insertion of a particular individual or group in a network of relations dominated by capitalist industry and commerce, often amounting to the loss of all but formal control of their own process of

1 A report on the 1968 situation of certain firms was prepared for an interministerial council meeting of the Senegalese government and stated "The increase in competition in foreign markets, and the competition from local secret and illega production of shoe-soles (using independent piece-workers for production of shoe-soles (using independent piece-workers for the cutting of rubber and foam) has led BATA to ask for a revision of the protection agreement from which it currently benefits" (Le Brun 1973). 
production; relative independence is exchanged for wage-labour. While the pretence of autonomy is kept up by both sides, the petty producer not only gets much of his materials and equipment from capitalist producers and merchants, but sells a part or all of his production to similar (though not the same) firms. A survey undertaken in Dakar in 1974 indicated that the number of petty producers dealing in some appreciable way with large firms was quite small; this is to be expected for many reasons.

Industrialisation in underdeveloped countries has not led to the establishment of the many backward and forward commercial linkages that it has in the now-developed regions of the world. Industrialisation has been partial and even though its influence is pervasive, it has affected only limited areas. Much of it has been externally oriented, supplying a particular metropolitan country or bloc of countries with basic raw materials, foodstuffs or manufactures. More recently, a part of the industrial system has been geared towards the production of commodities either for the maintenance of the administrative and industrial structures required by all aspects of the externally-oriented sector, or for the production of goods and services largely benefiting a privileged minority of the population.

Hence industry has a limited scope as well as a distorted orientation in most underdeveloped countries; one would not expect there to be much scope for petty producers to graft themselves onto this structure, given that the indigenous owner of wealth faces limitations on where he can profitably invest. The structure of industry permits little competition, hence enterprises which are intermediate both in size and role proliferate, while projects and potential investments outside the existing structure of industry remain unrealised.

The second and predominant trend involves the impoverishment of the mass of petty producers who are progressively prohibited from access to the raw materials, equipment and techniques necessary to earn even a basic urban-subsistence income. A study of petty producers in Dakar, conducted in 1973-74, showed that most of those who linked themselves through the market with large commercial or industrial firms achieved little progress. Only exceptional cases (comprising 2 to 3 per cent of the sample), through a long process of building up personal and business relationships and fulfilling basic economic and administrative criteria, had advanced appreciably; however, this constitutes a weak and numerically insignificant 'positive' trend. Most petty producers appear to be on quite another 'Iadder', the bottom rungs of which become more crowded each year. Obviously, quantitative measures of this situation must be treated with the utmost care; the subjective income figures for petty producers were around the level one would have expectedon average little different from the SMIG, the statutory industrial minimum rate of pay. Incomes were in many cases, however, much lower than this. The average artisan shoemaker/ repairer, working alone, had an income ranging from one third to one half of the SMIG.

However, the qualitative data were much more illuminating: the general opinion was that there was a crushing lack of work. This reflected the degree of competition, the poverty of their clients, the limited and expensive access to raw materials, equipment and services, and the state of 'recession' in which many considered themselves to be. Many of the petty producers interviewed appeared to have the characteristics of the stereotype underemployed man. However, this term should be used with caution; "underemployed' really indicates that the dominant form of activity-industrial production-has no direct need for the vast majority of petty producers. Directly, industry deals with its usual, relatively stable labour-force, plus a fluctuating number of casual workers some of whom may be petty producers at other times. There exists an indirect relationship between petty and industrial production inasmuch as petty producers provide not only many of the commodities necessary for the maintenance of the industrial labour-force, but also casual workers themselves, at a relatively low price (at much lower than industry could or would be prepared to produce). Thus petty producers contribute to both cheapening the cost of labour to industry and reducing the cost of reproducing labour-power. However, when the characteristic types of productive activity and the relationships these activities have with the dominant forms of industrial production and commercial distribution are put into their objective context, it is clear that if the term 'underemployed' must be used at all, it should be used as a verb indicating a lack of direct functionality $v i s-\grave{a}-v i s$ the dominant capitalist mode of production rather than to describe petty producers in terms of individual characteristics, i.e., an inability to make productive use of available working-time.

In terms only of their own type of activity and organisation, however, petty producers could be 
described as 'underemployed': there are relatively too many of them compared with the demand (in terms of popular bargaining power) for their products, and hence most of them suffer from a shortage of remunerative work. In terms of the other main form of productive activity, namely capitalist industry and commerce, they also appear to be 'underemployed', since the meagre backward linkages which exist are not commensurate with the large numbers of active petty producers, nor are such linkages particularly valuable in terms of the growth of the markets capitalist industry serves. When the status of petty producers is judged within the context of the relations existing between themselves and the industrialised urban economy, 'underemployment' can be seen in its true light, as a dualistic concept measuring the performance of petty producers according to criteria which only logically apply outside this restricted framework, and which ignore the relationships which give rise to phenomena usually rationalised as 'underemployment'.

A case-study of urban casual workers in Senegal showed that casual work in industry enables some of the less successful petty producers to supplement their insufficient incomes; it is not common, however, for petty producers to engage both in commodity production and wage-labour on an equal basis simultaneously, though combinations of wage-labour, individual production, commercial and other activities are commonly found among poorer urban inhabitants. Casual labour offers some income-earning opportunities to recent migrants until independent producing or trading opportunities arise, or disillusionment pushes the migrant back to his home village, or induces him to try elsewhere-another town, another country, or even Europe. Nevertheless, there are many who have made a 'career' of casual work. Most of them live in the poorer districts of the city and have dependents who may contribute little or nothing to their own upkeep. However, many casual workers have additional sources of income: monthly earnings are quite small, firequently paid by the day, and often indirectly. Most casual workers are unskilled, and those who previously received some training did not necessarily exercise those skills in the employment they eventually found.

The situation is obviously more complex for the petty producer who also sells his labour-power in industrial employment. Bettelheim (1972: 287-8) notes that:

"at the economic level itself, wages are subject to determination both by variations in the productivity of labour and by non-capitalist production relations. Within a complex social formation, such relations may indeed be combined with capitalist production relations. This is so, in a way that is particularly significant . . . in the under-industrialised countries, where many wage-earners are not 'pure wage-earners' ('freed' from their means of production) but are involved in other than capitalist relations of production. In cases like this, wages are often 'supplementary income' (which means that the relation between wages and the cost of reproducing labour-power is modified), for the worker's subsistence is partly based on relations of production that are other than capitalist."

Though he has in mind the more specific case of wage-workers who also engage in agricultural activities outside the capitalist mode of production, his comments are equally applicable to casual workers in capitalist industry who derive additional income from other, largely noncapitalist, sources such as petty production. Casual labour provides a cheap and expendable source of labour, ensuring that upward pressure on wages is limited by a large and visible labour supply. The wages of casual workers, like those of regular industrial employees, constitute a useful transfer of potential purchasing power into the city's poorer districts. Lastly, this floating labour-force frightens, chastens or disillusions both petty producers on the one hand, for petty producers is what they may become, and industrial employees on the other, since a claim to employment-stability is all that separates them from their less fortunate workmates.

The contemporary situation of petty production has serious consequences for both internal and external attempts to organise and transform it so that it can participate fully in the process of development. Strategies for such 'promotion' involve a clear political option, to be placed squarely on the shoulders of the State. Within the current situation of externally-oriented, underdeveloped countries, petty production cannot participate in any other way but a dependent and subordinate one (with the exception of the minority who succeed in relative terms in accumulating capital, capturing markets and establishing contractual relations and thereby moving out of petty production). If a country relies to a large extent upon imports to supply its industry (which in most cases merely engages in the production of consumption articles of a relatively luxury status. and is largely dominated by foreign capital) relatively unprofitable 
activities are left to such groups as the Lebanese in commerce or, to a much larger extent, to petty producers. The ILO report on Kenya (1972: 94, 505), while failing to draw the correct conclusions, did point out that the growth of petty production tends to be predominantly involutionary. State promotional schemes which 'cream off' a small number of petty producers for 'development' and discriminatory advancement, either in order to create viable small industrial enterprises, or to give the impression that transition is taking place in order to placate petty producers, ignore the causes of the problem, and fail to help those who most need assistance. Indeed, petty producers who are non-recipients of state promotion frequently allege that the State helps those who are already a long way along the road to small industrial production. Attempts by the State to encourage the evolution of small industries indicate some appreciation of the fact that some petty producers are able to expand even without aid. Apparently the problem is considered remediable, since much of the promotion undertaken in underdeveloped countries involves giving access to otherwise inaccessible credit facilities, guarantees, machinery and materials, and advice on management and book-keeping. Little importance appears to be given to the aggregate repercussions of such schemes: when lip-service is paid to such considerations, it is based upon a dualistic conception of the urban economy, hence the problems remain susceptible to marginal 'tinkering'.

Initially the State usually decides whether to give much to the 'chosen few' or a little to virtually everyone, usually opting for the former. Visitors and potential investors see the prestige cooperatives and small factories benefiting from state promotion and rarely visit the workshops of those who remain unaided. State preoccupation with the success of promoted enterprises may entail discriminatory treatment which severely handicaps the non-beneficiaries of state promotion. In open economies, this may not prevent promoted firms from falling victim to larger, local and/or foreign enterprises, whose expansionary strategies are not restricted by small budgets.

Another means by which the State can 'involve' small indigenous enterprises in the transactions of the advanced industrial sector, is by offering contracts for commodities the State wishes to procure. But the administrative criteria for acceptance by the State as a registered contractor may militate against certain small enterprises which, by their very nature, cannot fulfill the necessary conditions. Yet these marginal problems remain merely administrative details to be smoothed out; serious changes have to be made if individual 'entrepreneurs', owners of accumulated wealth, are not to take advantage of their privileged position by acting as brokers of such contracts with the State, thus siphoning off the much-needed revenues of petty producers through subcontracting systems and reducing such independent craftsmen to temporary hired labourers.

Hence the problems of positive state intervention are manifold and have wide repercussions. If promotional strategies for small-scale production are formulated without regard to the interests of self-centred and self-sustained growth, no real and positive change in the life-conditions of small-scale producers will be possible. In this context, we must inevitably pose the question "What type of evolution of petty production is compatible with an autonomous development strategy?" Due to the highly competitive nature of most petty production (including the provision of services), and the quasi-monopolistic nature of many of the sources of inputs, even if a small number of petty producers were able to evolve into petty capitalists with the provision of state aid, the almost inevitable outcome would be a more or less rapid concentration and differentiation of relative power, capacity, and production within the small-scale sector as opposed to the current situation of quasi-perfect competition. It is probable that certain petty producers who are non-beneficiaries of state promotion may find wage-work in the successfully promoted firms more remunerative than self-employed production. The majority, however, would be unable to find such work. Economies of scale and state promoted differentiation and discrimination would reduce access to raw materials and lower their market-share, thus worsening their situation. Some individuals and their families would benefit through employment effects, but the aggregate effect on productive employment would probably be negative. The majority of petty producers would find themselves less able either to reproduce their contemporary situation or maintain an already meagre clientele, and would be driven towards that fringe of petty production which almost exclusively depends upon discarded raw materials, recuperation, and the poorest possible clients. Promotion of this sort would not only tend to compound existing economic and social difficulties, but would also intensify the rate of impoverishment and 'marginalisation'. unless a massive programme of industrialisation and/or employment expansion were able to absorb those petty producers whose activities had become unviable. 
The crucial question, given this evaluation of current trends, relates to ways in which the present linkages might be transformed such that the devastating results outlined above might be avoided. Can existing relationships be used, or must they be transformed? Three general options are available: 1 . the laissez-faire approach, permitting uncontrolled and little understood processes to continue their 'natural' course; 2 . the promotional approach already indicated, 'creaming off' selected enterprises for transformation and launching into capitalist activities, more or less irrespective of their proposed milieu, and 3. positive promotion coupled with a thoroughgoing and global reappraisal of the economic system in which small-scale activities, and their probable successors (cooperative production units, etc.), might contribute and share in a real process of economic, social and cultural development based largely on the economy's orientation towards economic independence and self-centred development and growth.

The laissez-faire approach appeals simultaneously to policy-makers who either have an extreme dualist conception of the nature and operation of the urban and, indeed, national economy or a rather paternalist and romantic idea that artisanry is something which should be preserved, rather like an ancient monument, regardless of its position in the economy. Neither of these types of policy-maker believes the economy to be susceptible to structural change, even when such changes are so clearly required for the mass of the working population to participate in the sort of developnent outlined above.

The approach which selectively promotes a minority of already 'transitional' production units, so that they can successfully establish themselves at some level in the urban capitalist productive and/or distributive system, suffers from the same misconceptions as the laissez-faire approach, but actually and legally worsens the situation, not by formalising the informal sector but by actively increasing the degree of differentiation between productive units outside the capitalist production process at the very point where transition starts to evolve. This makes autonomous evolution in that direction unlikely if not impossible, thus placing control of the rate and nature of this evolution in the hands of the government, its advisors, and the heads of industry in the area. Hence this policy cuts off the mass of the urban petty producers from the means of maintaining their present situation, and conclusively debars all but a favoured and carefully selected few from evolution towards the establishment of more productive and remunerative activities.

Consequently, the usefulness of the existing linkages in improving the situation of petty producers becomes more and more doubtful: the remaining question poses the problem of transforming the present linkages and relationships in such a way that an all-inclusive development of production and distribution, involving and benefiting all sections of the population might take place. In order that this problem might even be considered, it is essential that a reappraisal of the operation of the entire economy be made with a view to orienting policy-making towards these concepts of development, and away from policies which merely reinforce the domination of interests and considerations irrelevant and alien to such development. In order that promotion, as one policy of transformation of petty production, might work, the relations between petty and industrial production must be clearly understood; where existing relationships conflict with or retard the realisation of popular development objectives, the relationships should be positively transformed. The nature of such changes will be governed by the situation in question, and not by any textbook list of criteria or plan of action, though we may well learn valuable lessons from the strategies already undertaken in or planned for countries which have taken a socialist road to development.

The question of the concrete policyrecommendations to fit specific cases is too complex and important a field to be dealt with in detail here. It may be worth mentioning, however, that in certain countries, Nigeria for example, small-scale production is being promoted (albeit selectively, and in this sense no differently from the Senegalese case) through the government transfer of surplus from multinational corporations to promotion projects. When foreign capital has an important stake in another sector of the economy (e.g., oil or wholesale commerce), it may be prepared to pander to the 'development'-oriented whims of the government in question. But what hope have the less well-endowed economies like Senegal of realising such transfers? Bourgeois theories of the nature and operation of the 'emergent' economy have largely determined policy for all forms of change in underdeveloped countries and yet the results have generally been far from encouraging in terms of the life-conditions of the mass of the population. What is required to replace such policies must emerge from new 
forms of political, as well as economic, organisation based on the productive and efficient use of the labour-force for the labour-force.

\section{References}

Bettelheim, Charles, 1972, Appendices in Arghiri Emmanuel's Unequal Exchange, New Left Books, London

Gerry, Chris, 1974, 'Petty producers and the urban economy: a case study of Dakar', ILO-WEP Research Working Paper No. 8. Geneva
International Labour Office, 1972, Employment, Incomes and Equality, ILO, Geneva

Le Brun, Olivier, 1973, 'Mecanismes de dissolution-conservation-développement de l'artisanat', Publication No. 27, Bureau Regional pour l'Education et le Développement en Afrique, UNESCO, Dakar

Le Brun, Olivier and Chris Gerry, 1975, 'Petty producers and Capitalism', Review of African Political Economy, No. 3 